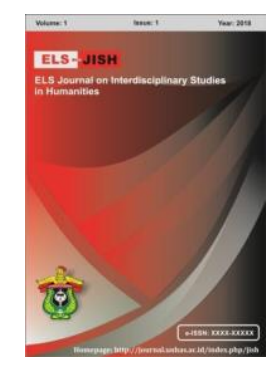

ELS-JISH

ELS Journal on Interdisciplinary Studies on Humanities

Volume 3 Issue 3, 2020

ISSN (print) : 2621-0843

ISSN (online) : 2621-0835

Homepage : http://journal.unhas.ac.id/index.php/jish

\title{
Skills Acquired during Teacher Training Programs (B.Ed \& M.Ed) and Skills Required in Actual Classroom
}

\author{
Zain ul abdin Rind \\ zain10763@gmail.com
}

\begin{abstract}
The aim of this study was to explore the differences between the skills developed in teacher training programs and the skills used in the classrooms. The population of this study was 937 Head Masters BPS-17 selected through IBA Sukkur. These Head Masters were selected for primary and Elementary schools by the government of Sindh. Data was collected from the participants through simple random sampling. The sample size for this study was 187 IBA Head Masters all over the Sindh. The questionnaire was used as a research tool to get the responses from IBA selected Head Masters about their teachers who are teaching in their schools. Data was analyzed through descriptive statistics. Participants' responses were analyzed through percentage, mean, and standard deviation. The mean score shows that the majority of teachers don't have planning $(M=2.31)$, presentation $(M=2.29)$, and management skills (2.34). The mean score of command over the subject factor is $(M=2.02)$, appropriate teaching methodologies factor $(M=2.28)$ and evaluation skills factor $(M=2.22)$ shows that majority of teachers don't have command over the subject and they do not use appropriate and modern teaching methodologies. Furthermore, teachers do not have evaluation skills to measure the students learning objectives and to know the students' strengths and weaknesses. It was concluded that whatever teachers learned in the professional trainings do not use those skills in the classrooms because most teachers are not interested in teacher training programs.
\end{abstract}

Keywords: Keywords: Skills, Policy, Acquired, Required, Evaluation

How to cite: Zain ul abdin Rind. (2020). Skills Acquired during Teacher Training Programs (B.Ed \& M.Ed) and Skills Required in Actual Classroom. ELS Journal on Interdisciplinary Studies in Humanities, 3(3), 433-439. DOI: https://doi.org/10.34050/elsjish.v3i3.10942

\section{Introduction}

In a progressive society, well aware citizens are required and this is only possible with effective education. Education is an important tool for the country's development. Education is a moral, social, emotional, and intellectual development of an individual and that person becomes an effective and efficient teacher for a society. He is regarded as a nation builder, role model, and character creator. Country and society cannot achieve the goal of success in every field of life without well-trained teachers. Darling Hammond (2006) pointed out that the importance of meaningful teaching has been increased rapidly in modern world and the standards of education and learning have been higher than

1, University of Sindh Jamshoro, Pakistan 
ever. This means changes in the entire education system, especially changes in the teaching methods. Teachers' training programs are helpful for producing effective teachers because there is a need for time to walk with the modern world. We have to polish the teacher's ability to cope with problems facing by children. It is also necessary for teacher's capacity building and to be aware of new methods of teaching and new technologies integrated into education. In the school system, the quality of teaching is the most critical factor affecting students' academic performance. In the name of improving the quality of teaching, millions of dollars are being invested in teacher professional development programs in Pakistan but programs often lack a direct and clear connection with classroom practice. One method seeks to improve quality by restricting access to teaching to only the "best and the brightest"

lqbal (1996) argued that Pakistan's ideology is based on religious beliefs. Abbasi (1995) believes that in Pakistan, teacher training is affected by insufficient training system, shortage of teachers, overcrowding of class rooms, insufficient equipment, textbook shortages, and lack of appropriate facilities. It has never helped the teachers to be creative, but offered to achieve outstanding achievements in their job. First time Wood's Dispatch (1854) recommended teacher training schools in each of the provinces. "Training schools should be opened for teachers of engineering, medicine, and law. Qualified teachers should be given better salary scales. The Dispatch further emphasized for providing scholarships to the teachers during training".

The father of nation Muhammad Ali Jinnah in his speech to the first education conference said: "We should redouble our efforts to make to enrich teacher education. This will strengthen the education system and enhance Pakistan's international presence. In this way, we can raise the status and honor of Pakistan in the community of Nations". First National Education Commission (1959) can be regarded as a backbone. General guidelines were provided for the teachers' training program in this commission to ensure: command on subject knowledge, psychological children knowledge for teachers and development of the children at all stages of their lives, to use latest teaching methodologies and professional ethics awareness. The New Education Policy (1970) highlights: "There is still much work to be done for the preparation of teachers in Pakistan. Higher basic education and professional training are needed". The New Education Policy (1979) recognizes the teachers are the most significant member to the entire system of education. It was recommended to evaluate the pre service teacher education program's curricula and appropriate modifications should be made. The Education Policy (1992) emphasizes: "The training of teachers will focus on the acquisition of practical skills. The role of teachers will be redefined. A system of punishment and rewards for teachers, based on performance evaluation, shall be introduced".

\subsection{Statement of the Problem}

The professional education programs are designed to train the teachers who are constructive contributors to the development and growth of a student. A literature study shows that there is a difference whatever the theory taught in teacher training program and the requirements in the real classroom. This study 
is conducted to explore the differences between the acquired and required skills..

\subsection{Objectives of the study}

a. To find out the perceptions of heads of schools about essential classroom skills learned by the trainee teachers.

b. To determine if there are differences between the skills developed in the teacher training program and the skills used in the classroom.

c. To identify the problems of the trainee teachers in attaining and implementing basic classroom skills.

\subsection{Research Questions}

a. What are the views of IBA Head Teachers about the degree to which the trainee teachers have acquired the required skills?

b. How can teachers make good use these skills in the real classroom?

c. What are the main problems for the trainee teachers in acquired and implementing basic classroom skills?

\subsection{Significance of the study}

The results of this study will be helpful for the teacher training institutions to formulate appropriate plans. The findings might be beneficial for those researchers who are interested to investigate more in future in the relevant field. The results of this study may also be helpful for curriculum developers to eliminate certain problems while designing teacher education courses.

\subsection{Delimitation of the study}

The current study was delimited to the 937 Head Masters (BPS-17) selected through IBA Sukkur in government primary and secondary schools all over the Sindh.

\section{Materials and Methods of Study}

\subsection{Research Design}

The study was descriptive in nature and the survey method was used to get the views of Head Masters about the teachers through questionnaires.

\subsection{Population}

The population of this study was 937 Head Masters selected through IBA Sukkur. These Head Masters were appointed in Primary and Elementary Schools of Government of Sindh.

\subsection{Sample and Sampling}

The sample size for this study was 187 IBA selected Head Masters and simple random sampling was used to collect data from Head Masters about the perception of teachers. 


\subsection{Research Tool}

The questionnaire was developed to get data from Head Teachers. The closed-ended questions were based on a five-point Likert Scale. In last the questionnaire had two open-ended questions.

\section{Results and discussion}

After the collection of quantitative data, it was analyzed through SPSS software. Descriptive statistics was used by using each of the questions on the Likert scale. The questionnaire was divided into ten factors. Summaries mean and standard deviation of Likert scale for the thirty-five questions, from Q1 to Q 35. These questions were checked on the 5-point Likert scale from " 1 -Strongly Disagree to 5-Strongly Agree" and the two open-ended questions were also there to get the answers from Head Masters.

\section{Descriptive Statistics}

\begin{tabular}{lccc}
\hline \multicolumn{1}{c}{ Factors } & N & Mean & Std. Deviation \\
\hline Lesson Planning Skills & 187 & 2.31 & .77 \\
\hline Lesson Presentation Skills & 187 & 2.29 & .73 \\
\hline Lesson Management Skills & 187 & 2.34 & .71 \\
\hline Maintaining Social Environment & 187 & 2.78 & 1.04 \\
\hline Command Over the Subject & 187 & 2.02 & .66 \\
\hline Appropriate Teaching Methodologies & 187 & 2.28 & .73 \\
\hline Maintaining Classroom Discipline & 187 & 3.05 & .95 \\
\hline Teachers Classroom Behaviour & 187 & 3.25 & .78 \\
\hline Checking of Home Work & 187 & 2.81 & .90 \\
\hline Evaluation Skills & 187 & 2.22 & .64 \\
\hline
\end{tabular}

\section{Discussion}

The factor wise Table represents the mean score of ten components; lesson planning skills, lesson presentation skills, lesson management skills, maintain the social environment, command over the subject, appropriate teaching methodologies, maintain classroom discipline, teacher classroom behaviour, Checking of homework, and Evaluation skills.

Data was analyzed through five-point likert Scale. The component 'lesson planning skills' explored the head teacher's opinion about the teacher's planning skills and preparation of lesson objectives according to the students need. The mean for this factor was $(M=2.31)$ \& the standard deviation was $(S D=.77)$ which shows teacher's lack of lesson planning skills. Teachers should prepare and plan their lessons to create good student's discipline and pay more attention to how planning can help them to improve effective classroom management (Moradi, 2019).

The second component 'lesson presentation skills' explored the head teacher's view about the classroom material effectively, interestingly presenting lessons, and involving students' in different learning activities. The mean for this factor was $(M=2.29)$ \& the standard deviation was $(S D=.73)$ which shows teachers do not have lesson presentation skills. 
The third component 'lesson management skills' explored head teacher's view about managing and organize lessons, linking new lessons to students' previous knowledge, carefully develop the course material, and then divide the learning material into sequences. The mean for this factor was $(M=2.34) \&$ the standard deviation was $(S D=.71)$ which shows teachers do not have lesson management skills.

The fourth component 'maintaining social environment' explored the head teacher's view about the classroom environment and student's interest in learning. The mean for this factor was $(M=2.78)$ \& the standard deviation was $(S D=1.04)$ which shows teachers maintain a good social environment.

The fifth component 'command over the subject' explored the head teachers' view about the subject knowledge and provides the latest information of the subject. The mean for this factor was $(M=2.02) \&$ the standard deviation was $(\mathrm{SD}=.66)$ which shows teachers do not have command over the subject.

The findings of this study are consistent with the study of Ofsted (2009) who pointed out that command on subject knowledge in primary schools teachers was usually accidental. The Component six 'appropriate teaching methodologies' explored head teacher's view about modern techniques, students' lower level thinking skills, different problem solving strategies, which stimulates confidence and motivate students towards learning. The mean for this factor was $(M=2.28)$ \& the standard deviation was $(S D=.73)$ which shows teachers do not use appropriate teaching methodologies and modern techniques of teaching in classrooms. The results of this study are also consistent with the results of Ali (2005) who argued that the teachers' method of teaching was traditional and the teacher training programs were also traditional.

The seventh component 'maintaining classroom discipline 'explored the head teacher's view about dealing with good classroom behaviour, misbehavior, and disruptive behaviour. The mean for this factor was $(M=3.05)$ \& the standard deviation was $(\mathrm{SD}=.95)$ which shows mostly teachers are maintaining good classroom discipline.

The eighth component 'teacher classroom behaviour 'explored the head teacher's view about teacher's classroom behaviour, experience in teaching and learning, and the teacher's flexibility, creativity, and adaptability. The mean for this factor was $(M=3.25)$ \& the standard deviation was $(S D=.78)$ which shows mostly teachers are maintaining good classroom behaviour.

The ninth component 'checking homework 'explored the head teacher's view about giving and checking homework. The mean for this factor was $(M=$ $2.81)$ \& the standard deviation was $(\mathrm{SD}=.80)$ which shows mostly teachers give and check homework.

The tenth and last component 'evaluation skills 'explored head teacher's view about teachers' evaluation techniques, teachers' judgment about student's performance and achievements, and the use of diagnostic evaluation to measure the strength and weaknesses. The mean for this factor was $(M=2.22)$ \& the standard deviation was $(\mathrm{SD}=.64)$ which shows mostly teachers do not 
have evaluation skills. The results of this study are also consistent with the results of the study conducted by Kaleem (2010) that the teachers do not use evaluation techniques properly and also the teachers are lacking the classroom management skills to maintain good discipline.

\section{Conclusion}

In light of this study, it is concluded that most teachers' do not use acquired skills in actual classrooms which they got through teacher training program. The teachers do not have lesson planning, presentation, and lesson management skills. They also don't have command over the subject and they do not use modern methods of teachings in their classrooms. They stayed with old methods of teaching as a purely teacher-centered lecture method. Furthermore, teachers do not have evaluation skills to measure the students learning objectives and to know the students' strengths and weaknesses. The heads of schools viewed that teachers do not use those techniques acquired in the teacher training program in the actual classroom because they are not interested in a teacher training program mostly teachers just attend training for remuneration. Some head teachers viewed the shortage of teachers and high enrollment is a reason for that. Some heads opined that new technique needs classroom material and A.V aids which government is not providing to us. Another reason which is not followed by education department is lack of monitoring and accountability. Furthermore, Head Masters opined that teachers have no capability and creativity to use modern technologies and methods is class rooms. Finally, it is concluded that there is a dire need to polish the teachers and highly qualified teachers are needed with high creativity and they must be trained from foreign countries to stand with the quality education. However, it is encouraging to note that teachers are maintaining a good social environment, good classroom discipline, and behaviour. Thus, it is finally concluded that whatever teachers acquired during teacher training program (B.ED \& M.Ed.) do not implement in actual classrooms.

\section{Recommendations}

> During training programs more concentration should be placed on planning skills.

$>$ Proper training with modern techniques and tools is needed.

- Teachers must have command over the subject and they should be updated in providing latest subject information.

- Teachers should use modern methods of teachings in their classrooms with modern tools to make classes student-centered.

$>$ Teachers should have evaluation skills to evaluate students. They must know about the types of evaluation formative and summative to know the students' strength and weaknesses.

\section{References}

Darling-hammond, L., Flook, L., Cook-harvey, C., Barron, B., Flook, L., Cookharvey, C., Darling-hammond, L., Flook, L., Cook-harvey, C., \& Barron, B. 
(2020). Implications for educational practice of the science of learning and development. Applied Developmental Science, 24(2), 97-140. https://doi.org/10.1080/10888691.2018.1537791

Jonsson, A., \& Lennung, S. A. (2011). Investigating the Development of Analytical Skills in Teacher Education. 2(July), 3-17.

Karakuş, M., \& Karakuş, F. (2017). Examining teaching of professional concepts in teacher training and investigating students ' cognitive structures regarding professional concepts. 12(24), 1230-1241. ttps://doi.org/10.5897/ERR2017.3416

Keow, T., Mohd, H., \& Hashimah, N. (2015). Soft Skills Integration in Teaching Professional Training: Novice Teachers 'Perspectives. Procedia - Social and Behavioral Sciences, 186, 835-840. https://doi.org/10.1016/j.sbspro.2015.04.204

Kuter, S. (2017). An Action Research on Developing Prospective Teachers Inquiry Skills An Action Research on Developing Prospective Teachers ' Inquiry Skills. October 2013. https://doi.org/10.5901/jesr.2013.v3n7p317

Malik, S. K., \& Urooj, T. (2012). Status of teacher education in Pakistan- $A$ problem centered approach. 46, 8581-8586.

Manasia, L., lanos, M. G., \& Chicioreanu, T. D. (2020). Pre-Service Teacher Preparedness for Fostering Education for Sustainable Development: An Empirical Analysis of Central Dimensions of Teaching Readiness. 4-6.

Momanyi, M. (2019). Enhancing Quality Teacher Education Programs in Developing Countries (Issue January 2016). https://doi.org/10.4018/978-14666-9948-9.ch010

Munir, K. (2006). Comparative Study of the Effectiveness of Formally trained and non- formally trained secondary school teachers MPhil thesis, Allama Iqbal Open University Islamabad, and p33-34.

Pachauri, D., \& Yadav, A. (2014). Importance of Soft Skills in Teacher Education Programme. 5(March), 22-25.

Rehmani, A. (2006). Teacher education in Pakistan with particular reference to teachers ' conceptions of teaching. February, 495-524.

Shami, A.P. (2010). Education in Pakistan, policies and policy formulation, National Book Founcation, Islamabad.

Singh, H. (2015). Strategies for Development of Life Skills and Global Competencies. November.

Stephenson, J., \& Stephenson, J. (2018). A Systematic Review of the Research on the Knowledge and Skills of Australian Preservice Teachers Australian Preservice Teachers. 43(4). 